\title{
LONG TERM IMPACT OF TILLAGE SYSTEMS, IRRIGATION AND NITROGEN ON SOIL PROPERTIES, GROWTH, YIELD, NUTRIENT UPTAKE AND QUALITY OF WHEAT (TRITICUM AESTIVUM L.)
}

\author{
P. K. SINGH ${ }^{1}$, ARVIND KUMAR ${ }^{2}$, BRIJESH KUMAR SINGH ${ }^{3}$, A. C. SINGH ${ }^{4}$ \& SACHIN KUMAR ${ }^{5}$ \\ ${ }^{1,5}$ Department of Agronomy, R.K. (P.G.) College, Shamli, C.C.S. University, Meerut, Uttar Pradesh, India \\ ${ }^{2}$ Agronomist Biotech India Technology, Department of Agronomy, R.K. (P.G.) College, \\ Shamli, C.C.S. University, Meerut, Uttar Pradesh, India \\ ${ }^{3}$ Research Scholar Department of Biotechnology, VCKV, Mohannagar, Department of Agronomy, \\ R.K. (P.G.) College, Shamli, C.C.S. University, Meerut, Uttar Pradesh, India \\ ${ }^{4}$ Assistant professor, Department of Agronomy, K.A. (P.G.) College, Shamli, \\ C.C.S. University, Meerut, Uttar Pradesh, India
}

\begin{abstract}
A field experiment was carried out consecutively for five years (2011-12 to 2015-16), in split-split plot design with three replications, to elucidate the long term impact of irrigation and nitrogen levels on soil physico-chemical properties, growth, yield and quality under different tillage systems in wheat. Long term zero tillage + mulch resulted significant reduction of bulk density from $1.37 \mathrm{Mg} / \mathrm{m} 3$ to $1.33 \mathrm{Mg} / \mathrm{m} 3$ at o-15 cm depth and a favorable shift in pH from an initial 7.74 to 7.45. Plants raised under zero tillage + mulch grew 6.75 percent tall and maintained 3.8 percent more shoots over conventional tillage, had 10.61, 7.52 and 12.84 percent higher biological, grain and straw yield, respectively over zero tillage. Similarly zero tillage + mulch resulted 15.58 and $14.29 \%$ higher Fe uptake over conventional tillage, and resulted $₹ 5146$ and $₹ 2850$ higher net return over zero tillage and conventional tillage, respectively. Plants enjoying seven irrigations had 6.0 percent higher dry matter as compared to four irrigations. Whereas, maximum grain yield (6.05 t/ha) was observed with six irrigations. Six irrigations had 8.0 percent higher grain yield over four irrigations and resulted 9.01, 9.63, 8.12, 13.04 and 40.66 percent higher uptake of $N, P, K, S$ and Fe over four irrigations, respectively. At $90 \mathrm{DAS}$, plants fertilized with $180 \mathrm{~kg} \mathrm{~N} / \mathrm{ha}$, retained 26.09 percent higher leaves, and maintained 2.27 percent higher total chlorophyll over $120 \mathrm{~kg} \mathrm{~N} / \mathrm{ha}$. Biological (15.27 t/ha) and straw yields $(9.74 \mathrm{t} / \mathrm{ha})$ were significantly higher with $180 \mathrm{~kg} \mathrm{~N} / \mathrm{ha}$. However maximum grain yield (5.99 t/ha) and harvest index (0.39) observed under $150 \mathrm{~kg} \mathrm{N/ha.}$ The protein content was highest with $180 \mathrm{~kg} \mathrm{~N} / \mathrm{ha}(12.33 \%)$, whereas, starch content, could not cross the level of significance. Nitrogen application @ $150 \mathrm{~kg} \mathrm{~N} / \mathrm{ha}$ resulted an additional return of ₹8983 over $120 \mathrm{~kg} \mathrm{~N}$.

KEYWORDS: Growth, Irrigation, Nitrogen, Nutrient, Quality, Tillage, Triticum Aestivum \& Yield
\end{abstract}

Received: Jun 22, 2017; Accepted: Jul 08, 2017; Published: Jul 31, 2017; Paper Id.: IJASRAUG201772

\section{INTRODUCTION}

Wheat (Triticum aestivum L. emend. Fiori \& Paol) assumes worldwide significance owing to its utilization as a human food and livestock feed, and is the most important crop of the northern India. It is being grown under diverse agro-climatic conditions on an acrege of 29.92 million ha with a production of 95.91 million tones and productivity of only $3075 \mathrm{~kg} / \mathrm{ha}$ against $4132 \mathrm{~kg} / \mathrm{ha}$ in China during 2016 (Anonymous, 2015). The 
higher wheat productivity in China is believed to be due to higher acreage under zero tillage, adoption of improved production technology i.e. nutrient management, appropriate irrigation scheduling and pest management. Hence, there is great scope to increase the productivity of wheat in India also.

Usually the rice is harvested from height of $10-15 \mathrm{~cm}$ above the ground, whose stubbles pose several problems during conventional land preparations require multiple tillage operations. Poor rice residue management and untimely and inadequate availability of power also aggravate the problem (Erenstein, 2009). These losses/ problems can be minimized/ handled through early seeding of wheat by adopting zero-tillage or reduced tillage techniques, which advance the crop sowing by 10-15 days. The wheat sown under zero-till drill system may solve the problems as rice stubbles after falling on the ground, may help in conserving the moisture and in longer run improves the physico-chemical environment for crop growth, reduces possibilities of soil erosion, conserves time and energy and decreases the overall cost of cultivation (HongYong Sun, et al., 2006).

\section{MATERIALS AND METHODS}

The experiment was conducted consecutively for five years from 2011-2012 to 2015-2016, at Research Farm of R.K.(P.G.) College, Shamli, U.P, India, to evaluate long term impact of irrigation and nitrogen levels on physico-chemical properties of soil, growth, yield attributes, yield, nutrient uptake and quality under different tillage systems in wheat. The experimental soil was sandy loam in texture, low in available $\mathrm{N}$ (275 kg N/ha), medium in available potassium (157 kg K /ha), and medium in available phosphorus $(22.9 \mathrm{~kg} \mathrm{P} / \mathrm{ha})$. The soil was found to be slightly alkaline in reaction with $\mathrm{p}^{\mathrm{H}}$ 7.74 and E.C. of $0.6 \mathrm{mhos} / \mathrm{cm}$ at $25^{\circ} \mathrm{C}$. The bulk density of the soil prior to wheat harvest was $1.37 \mathrm{Mg} / \mathrm{m}^{3}$ soil. The rice straw was applied @5 ton /ha. Wheat $c v$. PBW 343 was sown as per treatments. The line spacing was kept $20 \mathrm{~cm}$ apart. The sowing under zero tillage as well as zero tillage + mulch, were done with the help of Pantnagar zero till ferti-seed drill. The entire amount of phosphorus and potassium and half amount of nitrogen was applied at the time of sowing, whereas, the remaining half amount of nitrogen was applied at 25 DAS. The crop was weeded with the help of khurpi at 35 DAS sowing to check the weed below threshold level. The bulk density was determined treatment wise at three depths ie. $0-15$ $\mathrm{cm}, 15-30 \mathrm{~cm}$ and 30-45 $\mathrm{cm}$ depth after wheat harvest every year. However, the soil $\mathrm{p}^{\mathrm{H}}$ was determined treatment wise from the samples from the furrow slice every year after wheat harvesting. Treatment wise collected plant samples were oven dried at $60^{\circ} \mathrm{C}$ till constant weight. The dried samples were ground and digested with rapid nitric perchloric acid digestion method for the estimation of sulphur and Iron (Zoroski and Bureau, 1977). The cost of production was worked using prevailing market price of inputs and products during the year 2016.

The total chlorophyll content in leaves was determined by Dimethyl Sulfoxide Method (DMSO) and calculated with the help of following formula;

$20.2 \times \mathrm{A} 645+8.02+\mathrm{A} 663 \times \mathrm{V}$

Total Chlorophyll (mg/g Leaf Fresh Weight $)=$

$1000 \times \mathrm{W}$

Where, A, V and $\mathrm{W}$ were absorbance, final volume and weight of sample, respectively.

The uptake of N, P, K, and S by the crop was worked out by the following formula;

Whereas, the uptake of iron by the crop was worked out by following formula; 
Long Term Impact of Tillage Systems, Irrigation and Nitrogen on Soil Properties,

$$
\begin{aligned}
& \text { Nutrient Uptake }(\mathrm{kg} / \mathrm{ha})=\frac{\text { Content of nutrient }(\%)}{100} \times \text { yield }(\mathrm{kg} / \mathrm{ha}) \\
& \text { Iron Uptake }(\mathrm{kg} / \mathrm{ha})=\frac{\text { Content of iron }(\mathrm{ppm})}{10000 \times 100} \times \text { yield }(\mathrm{kg} / \mathrm{ha})
\end{aligned}
$$

\section{RESULTS AND DISCUSSIONS}

\section{Effect on Soil Physico-Chemical Properties}

Long term continuous adoption of zero tillage + mulch exhibited marked and significant change in bulk density at 0-15 cm and 15-30 cm depth, however the difference in bulk density at 30-45 cm depth was non significant. Lowest bulk density $\left(1.33 \mathrm{Mg} / \mathrm{M}^{3}\right)$ observed with zero tillage + mulch brought positive change in bulk density as well as soil $\mathrm{pH}$. Soil physico-chemical properties, i.e. bulk density at 0-15 and 15-30 cm depth and was significantly influenced by tillage systems during both the years (Table 1). Lowest bulk density of $1.33 \mathrm{Mg} / \mathrm{m}^{3}$ soil after harvesting of wheat at $0-15 \mathrm{~cm}$ depth was analyzed under no tillage + mulch incorporation, which was significantly lower than same noticed under conventional tillage $\left(1.38 \mathrm{Mg} / \mathrm{m}^{3}\right)$. Similar favorable change in bulk density (Decline in bulk density) was noticed at $15-30$ $\mathrm{cm}$ depth also. The lower bulk density under no tillage + mulch incorporation was attributed to increased organic matter addition in the furrow slice, whereas, lower bulk density at $15-30 \mathrm{~cm}$ depth might was due to less compaction effect on soil due to limited run of tractors. The result confirms the finding of Erenstein, O. (2009). A favorable shift in pH towards neutrality was observed due to zero tillage + mulch (7.45) followed by zero tillage (7.48), which was significantly lower than the same noticed under conventional tillage (7.73). The decline in soil $\mathrm{pH}$ might was due to formation of carbonic acid after decomposition of added rice residue. The result corroborates with the finding of Rahman, et al., (2011).

Water regimes showed significant influence on bulk density at 0-15 cm depth and could not cross the level of significance at other depths (Table 1). Lowest bulk density $\left(1.34 \mathrm{Mg} / \mathrm{M}^{3}\right)$ was noticed under four irrigations applied at CRI, Late jointing, Flowering, Milking, whereas highest bulk density at $0-15 \mathrm{~cm}$ depth $\left(1.38 \mathrm{Mg} / \mathrm{M}^{3}\right)$ was analyzed with seven irrigation. Although the lower value of $\mathrm{p}^{\mathrm{H}}$ was recorded under seven irrigations applied at 15 DAS, CRI, Late tillering, Late jointing, Flowering, Milking, but it could not cross the level of significance. The compaction effect created due to increased frequency of irrigation might resulted higher bulk density, which also maintained slightly reduced state of soil environment thus resulted slight reduction in soil $\mathrm{p}^{\mathrm{H}}$. The results are analogous to the findings of Katri et al., (2002).

Nitrogen levels did not show any significant impact on bulk density of soil. However, the $\mathrm{pH}$ was influenced significantly with application of nitrogen (Table 1) and was observed lowest under $180 \mathrm{~kg}$ N/ha (7.46). Relatively low bulk density with $180 \mathrm{~kg} \mathrm{~N} / \mathrm{ha}$ might was because of higher quantity of root biomass production and its incorporation in the soil. Whereas, a meager but significant reduction in soil $\mathrm{p}^{\mathrm{H}}$ might was due to acidic residual effect of additional nitrogen fertilization in $180 \mathrm{~kg} \mathrm{~N}$ treated plots. The finding corroborates with the result of Malhey et al., (2006).

\section{Effect on Growth}

Tillage systems exhibited significant influence on plant height, number of shoots, dry matter accumulation, leaf area as well as total chlorophyll content in leaves (Table 2). Maximum plant height at 60 DAS (61.2 cm), number of shoots (595 shoots $/ \mathrm{m}^{2}$ area), dry matter accumulation $\left(349.3 \mathrm{~g} / \mathrm{m}^{2}\right.$ area) was observed under zero tillage + mulch, which was 
significantly higher than the same recorded under zero tillage and was on par to the conventional tillage. Almost similar trend of response in respect of different growth parameters was observed at maturity also. At maturity, plants raised under zero tillage + mulch grew 6.75 percent tall and maintained 3.8 percent more shoots over conventional tillage. Highest leaf area and total chlorophyll content in leaves at 60 and 90 DAS also was observed under zero tillage + mulch (Table 2). At 60 DAS, plants under zero tillage + mulch retained 16.91 percent higher leaf surface than zero tillage alone. Similar trend of response of tillage systems on leaf area was noticed at 90 DAS also. Similarly, maximum total chlorophyll in leaves at 90 DAS (1.541 mg/g leaf fresh weight) was determined with the plants raised under zero tillage + mulch, which was significantly higher than the same recorded with zero tillage $(1.538 \mathrm{mg} / \mathrm{g}$ leaf fresh weight) and conventional tillage (1.527 $\mathrm{mg} / \mathrm{g}$ leaf fresh weight). Higher leaf area and total chlorophyll under zero tillage + mulch was due to release of essential nutrients after the decomposition of applied rice residues and maintaining conducive physico-chemical properties, for crop growth and development. Whereas, higher plant height, number of shoots and dry matter accumulation under zero tillage + mulch was attributed due to higher leaf area and ever maintenance of higher content of chlorophyll in their leaves which enabled the plants to synthesize higher quantity of photo-assimilates, and thus higher pace of growth. The Similar views were reported by Rahman, et al., (2011).

Significantly higher plant height $(97.4 \mathrm{~cm})$, number of shoots $\left(547\right.$ shoot $\left./ \mathrm{m}^{2}\right)$, dry matter accumulation $(1467.7$ $\mathrm{g} / \mathrm{m}^{2}$ area) at maturity was observed under seven irrigations applied at 15 DAS, CRI, late tillering, late jointing, flowering, milking and dough. Plants enjoying seven irrigations had 6.0 percent higher dry matter accumulation at maturity as compared to four irrigations. Similarly, at 60 DAS seven irrigations resulted highest leaf area $\left(419.4 \mathrm{~cm}^{2} / \mathrm{plant}\right)$ and total chlorophyll content $(1.518 \mathrm{mg} / \mathrm{g}$ leaf fresh weight), which was significantly higher than four irrigations. Similar trend in respect of leaf area and total chlorophyll content observed at 90 DAS also. The differences for growth parameters between seven irrigations to six irrigations were non significant. The higher pace of growth under seven irrigations might was due to ever supplementation of moisture, since very beginning till maturity of the crop, and also might be because of accelerated movement/ uptake of nutrients. Similar results were observed by Bhattacharyya et al., (2008).

Nitrogen levels too exhibited significant response on different growth parameters and total chlorophyll content in leaves (Table 2). Amongst nitrogen levels highest plant height at 60 DAS $(61.3 \mathrm{~cm})$, number of shoots $\left(597 \mathrm{shoots}^{2} \mathrm{~m}^{2}\right.$ area), dry matter $\left(366.3 \mathrm{~g} / \mathrm{m}^{2}\right)$, leaf area $\left(398.9 \mathrm{~cm}^{2} /\right.$ plant $)$ and total chlorophyll content $(1.574 \mathrm{mg} / \mathrm{g}$ leaf fresh weight) was analyzed with $180 \mathrm{~kg} \mathrm{~N} / \mathrm{ha}$, which, stood significantly higher than $120 \mathrm{~kg}$ N/ha and was on par to the $150 \mathrm{~kg}$ N/ha. Similar trend of response observed at 90 DAS and at maturity also. At maturity, application of $180 \mathrm{~kg} \mathrm{~N} / \mathrm{ha}$ resulted $4 \%$ taller plants, 10.01 percent more shoots $/ \mathrm{m}^{2}$ area and accumulated 17.84 percent higher dry matter yield over $120 \mathrm{~kg} \mathrm{~N} / \mathrm{ha}$. Similarly at 90 DAS, plants fertilized with $180 \mathrm{~kg} \mathrm{~N} /$ ha, retained 26.09 percent higher leaves, and maintained 2.27 percent higher total chlorophyll content in their leaves over $120 \mathrm{~kg} \mathrm{~N} / \mathrm{ha}$. Higher total chlorophyll content in leaves with $180 \mathrm{~kg} \mathrm{~N}$ might was due to ever and adequate supply of nitrogen, which is a substrate for synthesis of chlorophyll, growth hormones and assimilation of protein in plants whereas, higher leaf area, plant height and number of shoots might was attributed to higher total chlorophyll content in plant leaves, which enabled the plants to utilize maximum radiant energy thus higher growth. Result corroborates the findings of Katri, et al., (2002).

\section{Effect on Yield Attributes and Yields}

Tillage treatment showed significant effect on different yield attributes, yields, and harvest index of wheat (Table 3). Highest number of spikes $\left(411 / \mathrm{m}^{2}\right)$, number of grains/spike (49 grains), grain yield/ spike (1.94 g) and 1000-grain 
Long Term Impact of Tillage Systems, Irrigation and Nitrogen on Soil Properties, Growth, Yield, Nutrient Uptake and Quality of Wheat (Triticum Aestivum L.)

weight (43.53 g) observed under zero tillage + mulch, whereas, lowest value of these parameters was recorded with zero tillage alone. Higher value of different yield attributes under zero tillage + mulch might was due to its favorable impact on different soil physico- chemical properties, (bulk density, soil $\mathrm{p}^{\mathrm{H}}$ and buildup in organic carbon status) and ever and continuous availability of essential plant nutrients after decomposition of added straw mulch (Akhtar, 2006). Biological $(15.09 \mathrm{t} / \mathrm{ha})$ grain $(5.72 \mathrm{t} / \mathrm{ha})$ and straw yield $(9.37 \mathrm{t} / \mathrm{ha})$ also were noticed highest with zero tillage + mulch, which was significantly higher than zero tillage and was statistically on par to the conventional tillage. Zero tillage + mulch recorded 10.61, 7.52 and 12.84 percent higher biological, grain and straw yield, respectively over zero tillage alone. Maximum harvest index (0.39) was observed under zero tillage, which was significantly higher than conventional tillage (0.38) and zero tillage + mulch (0.38). Higher yields under zero tillage + mulch might was attributed to higher value of different yield attributing characters. Whereas, higher harvest index under zero tillage alone was due to its respective higher grain yield. The result corroborates the findings of Kumar et al., (2013).

Irrigation schedules did not show significant effect on various yield attributes, although maximum number of spikes (387 spikes $/ \mathrm{m}^{2}$ area), grains per spike (49 grains /spike) observed with seven irrigations. However, highest grain yield per spike (2.06 g/spike) and 1000-grain weight (42.58 g) was recorded under six irrigations (Table 3). Significantly higher biological (16.14 t/ha) and straw yield (10.30 t/ha) was recorded under seven irrigations which, was significantly higher than four irrigations and was on par to the six irrigations. However, maximum grain yield (6.05 t/ha) observed with six irrigations. The plots enjoying six irrigations had 8.0 percent higher grain yield over four irrigations. Relatively less grain yield with seven irrigations might was due to partial crop lodging at the time of grain filling due to excessive crop growth. Higher value of biological and straw yield with seven irrigations was attributed to higher value of different growth parameters. Harvest index also was influenced significantly with irrigation levels and was noticed maximum with four irrigations (0.39). Lowest harvest index (0.36) was recorded under seven irrigations. Low harvest index with seven irrigations might was due to comparatively higher biological and low grain yield observed. The results confirm the findings of Li et al., (2007).

In likewise irrigation regimes, the nitrogen levels also did not show significant influence on different yield attributes (Table 3). Though maximum spikes (389 spikes/ $\mathrm{m}^{2}$ area), and number of grains per spike ( 47 grains) observed with $180 \mathrm{~kg} \mathrm{~N} / \mathrm{ha}$, whereas, highest grain yield per spike (1.96 g) and 1000-grain yield (42.448g) recorded under $150 \mathrm{~kg}$ $\mathrm{N} /$ ha. Higher number of spikes and number of grains per spike with $180 \mathrm{~kg} \mathrm{~N}$, might were attributed to higher pace of growth and maintaining higher content of chlorophyll whereas, relatively low grain yield and 1000-grain weight with 180 $\mathrm{kg} \mathrm{N}$ might was probably due to partial crop lodging observed at the time of grain filling. Biological (15.27 t/ha) and straw yields $(9.74 \mathrm{t} / \mathrm{ha})$ were significantly higher with $180 \mathrm{~kg} \mathrm{~N} / \mathrm{ha}$. However, maximum grain yield (5.99 t/ha) and harvest index (0.39) observed under $150 \mathrm{~kg} \mathrm{~N} / \mathrm{ha}$. Plots supplied with $150 \mathrm{~kg}$ N/ha yielded 7.0 percent higher grain yield over 120 $\mathrm{kg} \mathrm{N} / \mathrm{ha}$. Higher yields with $150 \mathrm{~kg} \mathrm{~N}$ application might was attributed to higher grain yield/ spike and higher 1000-grain weight. Slightly lesser yield with $180 \mathrm{~kg} \mathrm{~N} / \mathrm{ha}$ might was due to increased incidence of yellow rust and partial crop lodging. The results are in accordance to Abdul Basir, et al., (2015).

\section{Effect on Nutrient Uptake and Quality}

The uptake of $\mathrm{N}, \mathrm{P}, \mathrm{K}, \mathrm{S}$ and Fe significantly influenced by tillage systems, irrigation schedules and nitrogen levels in wheat (Table 4). Zero tillage + mulch resulted highest uptake of N (159.1 kg N/ha), P (27.4 kg P/ha), K (152.8 kg $\mathrm{K} / \mathrm{ha}), \mathrm{S}$ ((14.7 kg S/ha) and Fe (1120 g Fe/ha), which was significantly higher than the same observed with zero tillage 
alone (146.16 kg N, $25.4 \mathrm{~kg} \mathrm{P}, 132.6 \mathrm{~kg} \mathrm{~K}, 12.9 \mathrm{~kg} \mathrm{~S}$ and $910 \mathrm{~g} \mathrm{Fe} / \mathrm{ha})$. The potassium and iron uptake recorded with zero tillage + mulch stood significantly higher than conventional tillage (132.2 kg K and $980 \mathrm{~g} \mathrm{Fe} / \mathrm{ha})$, whereas, the uptake of $\mathrm{N}$, $\mathrm{P}$ and $\mathrm{S}$ remained at par. Zero tillage + mulch resulted 15.58 and $14.29 \%$ higher Fe uptake over conventional tillage system. The higher uptake of nutrients by the crop at harvesting might be attributed to higher biomass yield. The results are in conformity with findings of Malhi et al., (2006). The protein and starch content were statistically not influenced due to tillage systems (Table 4).

The irrigation schedules also showed a marked and significant difference in uptake of N, P, K, S and Fe. Whereas, the differences in protein and starch content in wheat grains remained statistically non significant (Table 4). Amongst irrigation schedules, highest uptake of nitrogen (176.31 kg N/ha), phosphorus (27.8 kg P/ ha), potassium (146.8 kg K/ ha), sulphur (15.6 kg S/ha) and iron (1280 g Fe/ ha) were recorded under seven irrigation. However, lowest uptake of N (156.86 $\mathrm{kg} \mathrm{N} / \mathrm{ha}), \mathrm{P}(24.9 \mathrm{~kg} \mathrm{P} / \mathrm{ha}), \mathrm{K}(135.7 \mathrm{~kg} \mathrm{~K} / \mathrm{ha}), \mathrm{S}$ (13.8 kg S/ha) and Fe (910 g Fe/ha) was analyzed under plots receiving four irrigations applied at CRI, late tillering, late jointing and flowering. Application of seven irrigations had 9.01, 9.63, 8.12, 13.04 and 40.66 percent higher uptake of N, P, K, S and Fe over four irrigations, respectively. Higher uptake of N, P, $\mathrm{K}$ and $\mathrm{S}$ might were attributed to higher biomass yield. Whereas, markedly higher uptake of Fe, was due to higher biomass yield as well as creation of slightly reduced soil state which enhanced the solubility and uptake of iron. The result corroborates the finding of Bhattacharyya et al., (2008).

Nitrogen levels also had significant effect on the uptake of N, P, K, S and Fe and also on the content of proteins in wheat grains. Whereas, difference in starch content among N levels, was statistically non significant (Table 4). Application of $180 \mathrm{~kg} \mathrm{~N} /$ ha resulted $17.35,16.27,7.60,16.78$ and 27.72 per cent higher N, P, K, S and Fe uptake, respectively over 120 $\mathrm{kg} \mathrm{N} /$ ha. Similarly the protein content also was highest with $180 \mathrm{~kg} \mathrm{~N} / \mathrm{ha}(12.33 \%)$. The higher uptake of P, K, S as well as Fe with $180 \mathrm{~kg} \mathrm{~N} /$ ha might were due higher biological yields. However, increased uptake of N and protein content with $180 \mathrm{~kg} \mathrm{~N} /$ ha was due to increased substrate availability for the synthesis of proteins. The results are in accordance to findings of Singh et al., (2009).

\section{Economics}

The tillage systems varied for their cost involvement for wheat production. Maximum cost incurred with conventional tillage ( $₹ 23850 /$ ha ) and least cost of production was with zero tillge ( $₹$ 19516/ha). Highest gross return ( ₹ 97920 /ha ), net return ( ₹ 75220 /ha ), obtained with zero tillage + mulch. However highest output: input ratio (4.59) and B:C ratio (3.59) was obtained with zero tillage. Zero tillage + straw mulch resulted $₹ 5146$ and $₹ 2850$ higher net return over zero tillage and conventional tillage, respectively. Similarly irrigation levels also showed marked variation on economics of wheat production. Highest cost of production ( $₹ 25700 /$ ha $)$ was associated with seven irrigations done at 15 DAS, CRI, Late tillering, Late jointing, Flowering, Milking, Dough. Whereas, Highest gross return( ₹ 103530 /ha ), net return ( ₹ 78930 /ha )was obtained under six irrigations. Maximum output: input ratio (4.34) and B:C ratio (3.34) was obtained under five irrigations. Besides, tillage systems and irrigation levels nitrogen also had immense impact on economics of wheat production (Table3). Maximum cost of cultivation ( $₹ 23220$ /ha ), was with $180 \mathrm{~kg}$ N/ha. But highest gross return ( $₹ 98430$ /ha ), net return( $₹ 75408$ /ha ), output input ratio (4.28) and B:C ratio( 3.28) was obtained with $150 \mathrm{~kg} \mathrm{~N} / \mathrm{ha}$.

From the findings of long term experimentation it is clearly evident that zero tillage $+5 \mathrm{t} / \mathrm{ha}$ mulch, had favorable impact on soil bulk density of the root zone and ameliorated the soil $\mathrm{p}^{\mathrm{H}}$, was able to supply additional quantity of $\mathrm{N}$, $\mathrm{P}$, $\mathrm{K}$, 
Long Term Impact of Tillage Systems, Irrigation and Nitrogen on Soil Properties, Growth, Yield, Nutrient Uptake and Quality of Wheat (Triticum Aestivum L.)

$\mathrm{S}$ and Fe to the plant and produced highest grain yield of good quality as well and had a net gain of $₹ 2850 /$ ha over conventional tillage. Irrespective of tillage systems irrigation schedule with six irrigations applied at CRI, Late tillering, Late jointing, Flowering, Milking, dough and application of $150 \mathrm{~kg} \mathrm{~N} /$ ha gave significant response. Increasing levels of irrigation beyond six irrigations and nitrogen beyond $150 \mathrm{~kg} \mathrm{~N}$ had no added advantage. Nitrogen application@150 kg N /ha resulted an additional return of ₹ 8983 over $120 \mathrm{~kg}$ N. Similarly, six irrigations resulted ₹ 1680/ha additional return over seven irrigations. Thus, the wheat should be raised under zero tillage with rice straw incorporation and should be given six irrigations and fertilized with $150 \mathrm{~kg} \mathrm{~N} / \mathrm{ha}$ to have maximum utilization of our resources, restoration of soil fertility and physico- chemical conditions, to reduce environmental pollutions due to running of tillage machineries and also for augmentation of farm and farmers profitability.

\section{REFERENCES}

1. Abdul Basir, Mohammad Tariq Jan, Mukhtar Alam, Abdul Sattar Shah, Khilwat Afridi, Mohammad Adnan, Khalid Ali and Ishaq Ahmad Mian 2015. Impact of tillage, stubble mulch management and nitrogen on wheat production and soil properties. Canadian Journal of Soil Sci.139: 1-8.

2. http//www.agricoop.nic.in., Agricultural Statistics at a Glance 2015. Ministry of Agriculture Cooperation and Marketing, New Delhi.

3. Akhtar, M.R. 2006. Impact of resource conservation technologies for sustainability of irrigated agriculture in PunjabPakistan. Pakistan Journal of Agricultural Research 44 (3): 239-25.

4. Baksh, K., I. Hassan, and A. Maqbool 2005. Impact assessment of zero-tillage technology in rice-wheat system: A case study from Pakistani Punjab. Electronic Journal of Environmental, Agricultural and Food Chemistry 4 (6): 1132-1137.

5. Bhattacharyya, R., Kundu, S., Pandey, S.C., Singh, K.P. and Gupta, H.S. 2008. Tillage and irrigation effects on crop yields and soil properties, under the rice-wheat system in the Indian Himalayas. Agric. Water Managt. 95: 993-1002.

6. Bijay Singh, Y.H.S., S.E. Johnson Beebout, Y. Singh, and R.J. Buresh 2008. Crop residue management for lowland rice-based cropping systems in Asia. Advances in Agronomy 98: 117-199.

7. Dash, R. and Verma, S.C. 2003. Management of weeds, nitrogen and tillage operations in wheat (Triticum aestivum) sown after puddled rice (Oryza sativa). Indian J. Agric. Sci. 73(5): 286-288.

8. Erenstein, O. 2009a. Adoption and impact of conservation agriculture based resource conserving technologies in South Asia. In Proceedings of the $4^{\text {th }}$ World Congress on Conservation Agriculture, February 4-7, 2009, New Delhi, India.

9. Hong-Yong Sun, Chang-Ming Liu, Xi-Ying Zhang, Yan-Jun Shen Yong and Qiang Zhang 2006. Effects of irrigation on water balance, yield and WUE of winter wheat in the North China Plain. Agricultural Water Managmt. 85: 211-218

10. Irfan Aziz, Tariq Mahmood and K. Rafiq Islam 2013. Effect of long term no tillage and conventional tillage practices on soil qualities. Soil and Tillage Research 131: 26-35.

11. Katri, R.S., Goel, A.C. and Malik, R.K. 2002. Comparative wheat crop performance in bed sowing and conventional flat sowing in rice-wheat system under different irrigation levels. Haryana Agric. Univ. Res. J. 32(1): 11-18.

12. Li H., Gao H., Wu H., Li W., Wang X., He J. 2007. Effects of 15 years of conservation tillage on soil structure and productivity of wheat cultivation in northern China. Aust J. Soil Res. 45: 344-350.

13. Rahman, M.H., A. Tanka and S. Hoque 2011. Long term effects of tillage on physico-chemical properties of modified Andisols of north east Thonshu Island. Communication in Soil Science and Plant Analysis 34 (11-12):1743-1757. 
14. S. S. Malhi, R. Lemke, Z. H. Wang and B. S. Chhabra 2006. Tillage, nitrogen and crop residue effects on crop yield, nutrient uptake, soil quality, and greenhouse gas emissions. Soil and Tillage Research 90:171-183.

15. V. Kumar, Y.S. Saharawat, M.K. Gathala, A.S. Jas, S. K. Singh, N. Chaudhary and Jat, M.L. 2013. Effect of different tillage and seedling methods on energy-use efficiency and productivity of wheat in the Indo-Gangetic plains. Field Crops Research 142:1-8.

16. Y. Singh, R.K. Gupta, G. Singh, J. Singh, H.S. Sindhu and B. Singh 2009. Nitrogen and residue management effects on agronomic productivity and nitrogen use efficiency in rice-wheat system in Indian Punjab. Nutrient Cycling in Agroecosystems 84:141-154.

17. Zoroski, R.J. and Bureau, R.G. 1977. A rapid nitric perchloric acid digestion method for multi element tissue analysis. Communication in Soil Science and Plant Analysis 8 (5): 425-436.

\section{APPENDICES}

Table 1: Long Term Impact of Tillage Systems, Irrigation and Nitrogen Levels on Soil Physico-Chemical Properties

\begin{tabular}{|c|c|c|c|c|c|c|c|c|}
\hline \multirow{3}{*}{ Treatment } & \multicolumn{6}{|c|}{ Bulk Density (Mg / $\left.\mathrm{M}^{3}\right)$} & \multirow{2}{*}{\multicolumn{2}{|c|}{ Soil pH }} \\
\hline & \multicolumn{2}{|c|}{ 0-15 cm Depth } & \multicolumn{2}{|c|}{ 15-30 Cm Depth } & \multicolumn{2}{|c|}{$30-45 \mathrm{~cm}$ Depth } & & \\
\hline & Initial & Final & Initial & Final & Initial & Final & Initial & Final \\
\hline \multicolumn{9}{|l|}{ Tillage systems } \\
\hline $\begin{array}{l}\mathrm{Z}_{1}-\text { Conventional tillage } \\
(6 \text { harrowing }+ \text { planking })\end{array}$ & 1.37 & 1.38 & 1.62 & 1.65 & 1.68 & 1.67 & 7.74 & 7.73 \\
\hline $\mathrm{Z}_{2}-$ Zero tillage & 1.37 & 1.35 & 1.62 & 1.62 & 1.68 & 1.67 & 7.74 & 7.48 \\
\hline $\mathrm{Z}_{3}-$ Zero tillage + mulch & 1.37 & 1.33 & 1.62 & 1.61 & 1.68 & 1.65 & 7.74 & 7.45 \\
\hline S.Em. \pm & & 0.009 & & 0.007 & & 0.02 & & 0.07 \\
\hline C.D. $(P=0.05)$ & & 0.03 & & 0.02 & & NS & & 0.24 \\
\hline \multicolumn{9}{|l|}{ Irrigation levels } \\
\hline $\begin{array}{l}\mathrm{I}_{1}=\text { Four irrigations (CRI, late } \\
\text { jointing, flowering, milking) }\end{array}$ & 1.37 & 1.34 & 1.62 & 1.62 & 1.68 & 1.66 & 7.74 & 7.74 \\
\hline $\begin{array}{l}\mathrm{I}_{2}=\text { Five irrigations (CRI, late } \\
\text { tillering, late jointing, flowering, } \\
\text { milking) }\end{array}$ & 1.37 & 1.35 & 1.62 & 1.63 & 1.68 & 1.67 & 7.74 & 7.65 \\
\hline $\begin{array}{l}\mathrm{I}_{3}=\text { Six irrigations (CRI, late } \\
\text { tillering, late jointing, flowering, } \\
\text { milking, dough) }\end{array}$ & 1.37 & 1.37 & 1.62 & 1.64 & 1.68 & 1.68 & 7.74 & 7.55 \\
\hline $\begin{array}{l}\mathrm{I}_{4}=\text { Seven irrigations (15 DAS, } \\
\text { CRI, late tillering, late jointing, } \\
\text { flowering, milking, dough) }\end{array}$ & 1.37 & 1.38 & 1.62 & 1.65 & 1.68 & 1.68 & 7.74 & 7.52 \\
\hline S.Em. \pm & & 0.01 & & 0.006 & & 0.02 & & 0.11 \\
\hline C.D. $(\mathrm{P}=0.05)$ & & 0.03 & & NS & & NS & & NS \\
\hline \multicolumn{9}{|l|}{$\begin{array}{l}\text { Nitrogen levels } \\
(\mathrm{kg} \mathrm{N} / \mathrm{ha})\end{array}$} \\
\hline $\mathrm{N}_{1}-120 \mathrm{~kg} \mathrm{~N} / \mathrm{ha}$ & 1.37 & 1.38 & 1.62 & 1.62 & 1.68 & 1.65 & 7.74 & 7.73 \\
\hline $\mathrm{N}_{2}-150 \mathrm{~kg} \mathrm{~N} / \mathrm{ha}$ & 1.37 & 1.37 & 1.62 & 1.62 & 1.68 & 1.67 & 7.74 & 7.48 \\
\hline $\mathrm{N}_{3}-180 \mathrm{~kg} \mathrm{~N} / \mathrm{ha}$ & 1.37 & 1.36 & 1.62 & 1.60 & 1.68 & 1.66 & 7.74 & 7.46 \\
\hline S.Em. \pm & & 0.005 & & 0.008 & & 0.02 & & 0.09 \\
\hline C.D. $(\mathrm{P}=0.05)$ & & NS & & NS & & NS & & 0.26 \\
\hline
\end{tabular}

*DAS = Days After Sowing, NS= Non significant, Initial=before experimentation, Final= after five years of continuous experimentation

Table 2: Effect of Tillage Systems, Irrigation and Nitrogen Levels on Growth and Total Chlorophyll Content of Wheat (Mean of Five Years)

\begin{tabular}{|c|c|c|c|c|c|c|c|c|c|c|}
\hline \multirow[t]{2}{*}{ Treatment } & \multicolumn{2}{|c|}{$\begin{array}{l}\text { Plant Height } \\
(\mathrm{cm})\end{array}$} & \multicolumn{2}{|c|}{ Shoots $/ \mathbf{m}^{2}$} & \multicolumn{2}{|c|}{$\begin{array}{l}\text { Dry Matter } \\
\text { (g/m² Area) }\end{array}$} & \multicolumn{2}{|c|}{$\begin{array}{c}\text { Leaf Area } \\
\left(\mathrm{cm}^{2} / \text { Plant }\right)\end{array}$} & \multicolumn{2}{|c|}{$\begin{array}{c}\text { Total } \\
\text { Chlorophyll } \\
\text { (Mg/G Leaf } \\
\text { Fresh Weight) }\end{array}$} \\
\hline & 60 DAS & Maturity & 60 DAS & Maturity & 60 DAS & Maturity & 60DAS & 90 DAS & 60DAS & 90DAS \\
\hline Tillage systems & & & & & & & & & & \\
\hline $\begin{array}{l}\mathrm{Z}_{1} \text { - Conventional } \\
\text { tillage }(6 \text { harrowing }+ \\
\text { planking) }\end{array}$ & 58.2 & 87.4 & 572 & 522 & 348.7 & 1452.2 & 425.2 & 525.2 & 1.537 & 1.527 \\
\hline
\end{tabular}


Long Term Impact of Tillage Systems, Irrigation and Nitrogen on Soil Properties,

Growth, Yield, Nutrient Uptake and Quality of Wheat (Triticum Aestivum L.)

\begin{tabular}{|c|c|c|c|c|c|c|c|c|c|c|}
\hline \multicolumn{11}{|c|}{ Table 2: Contd., } \\
\hline$Z_{2}$-Zero tillage & 56.0 & 87.3 & 526 & 475 & 304.8 & 1275.0 & 365.6 & 398.3 & 1.566 & 1.538 \\
\hline $\begin{array}{l}Z_{3}-\text { Zero tillage }+ \\
\text { mulch }\end{array}$ & 61.2 & 93.2 & 595 & 542 & 349.3 & 1475.5 & 426.7 & 545.6 & 1.570 & 1.541 \\
\hline S.Em. \pm & 1.42 & 1.48 & 5.64 & 5.62 & 3.53 & 27.39 & 8.09 & 8.44 & 0.001 & 0.001 \\
\hline C.D. $(P=0.05)$ & 4.93 & 5.14 & 19.49 & 19.28 & 12.21 & 94.67 & 28.1 & 29.3 & 0.002 & 0.002 \\
\hline \multicolumn{11}{|l|}{ Irrigation levels } \\
\hline $\begin{array}{l}\mathrm{I}_{1}=\text { Four irrigations } \\
\text { (CRI, late jointing, } \\
\text { flowering, milking) }\end{array}$ & 56.6 & 86.6 & 557 & 507 & 324.5 & 1384.2 & 298.6 & 396.2 & 1.543 & 1.514 \\
\hline $\begin{array}{l}\mathrm{I}_{2}=\text { Five irrigations } \\
\text { (CRI, late tillering, } \\
\text { late jointing, } \\
\text { flowering, milking) }\end{array}$ & 61.3 & 91.4 & 589 & 539 & 359.6 & 1405.5 & 355.3 & 462.4 & 1.541 & 1.515 \\
\hline $\begin{array}{l}\mathrm{I}_{3}=\text { Six irrigations } \\
\text { (CRI, late tillering, } \\
\text { late jointing, } \\
\text { flowering, milking, } \\
\text { dough) }\end{array}$ & 65.6 & 95.8 & 596 & 546 & 389.7 & 1413.0 & 398.6 & 489.3 & 1.543 & 1.516 \\
\hline $\begin{array}{l}\mathrm{I}_{4}=\text { Seven irrigations ( } \\
15 \text { DAS, CRI, late } \\
\text { tillering, late jointing, } \\
\text { flowering, milking, } \\
\text { dough) }\end{array}$ & 67.2 & 97.4 & 597 & 547 & 397.6 & 1467.7 & 419.4 & 531.6 & 1.540 & 1.518 \\
\hline S.Em. \pm & 1.43 & 1.47 & 2.79 & 2.71 & 3.76 & 22.18 & 9.8 & 10.1 & 0.0006 & 0.0011 \\
\hline C.D. $(\mathrm{P}=0.05)$ & 4.32 & 4.37 & 8.29 & 8.26 & 11.19 & 65.87 & 29.3 & 30.2 & 0.0019 & 0.0033 \\
\hline \multicolumn{11}{|l|}{$\begin{array}{l}\text { Nitrogen levels (kg } \\
\mathrm{N} / \mathrm{ha})\end{array}$} \\
\hline $\mathrm{N}_{1}-120$ & 58.1 & 88.0 & 545 & 495 & 316.4 & 1353.8 & 328.3 & 419.7 & 1.540 & 1.540 \\
\hline$N_{2}-150$ & 59.6 & 89.4 & 553 & 503 & 351.2 & 1403.0 & 329.6 & 431.4 & 1.552 & 1.542 \\
\hline$N_{3}-180$ & 61.3 & 91.5 & 597 & 545 & 366.3 & 1595.8 & 398.9 & 529.2 & 1.574 & 1.575 \\
\hline S.Em. \pm & 1.16 & 1.15 & 2.89 & 2.83 & 3.44 & 22.19 & 10.61 & 9.86 & 0.003 & 0.003 \\
\hline C.D. $(\mathrm{P}=0.05)$ & 3.24 & 3.27 & 8.20 & 8.12 & 9.77 & NS & 30.2 & 27.9 & 0.006 & 0.006 \\
\hline
\end{tabular}

*DAS = Days after sowing, NS= Non significant

Table 3: Effect of Tillage Systems, Irrigation and Nitrogen Levels on Yield Attributes, Yields and Harvest Index of Wheat (Mean of Five Years)

\begin{tabular}{|c|c|c|c|c|c|c|c|c|}
\hline \multirow[b]{2}{*}{ Treatment } & \multicolumn{4}{|c|}{ Yield Attributes } & \multicolumn{3}{|c|}{ Yields (T/Ha) } & \multirow[b]{2}{*}{$\begin{array}{l}\text { Harvest } \\
\text { Index }\end{array}$} \\
\hline & $\begin{array}{l}\text { Spikes } \\
/ \mathbf{m}^{2} \text { Area }\end{array}$ & $\begin{array}{l}\text { Grains } \\
\text { /Spike }\end{array}$ & $\begin{array}{l}\text { Yield/ } \\
\text { Spike } \\
\text { (g) }\end{array}$ & $\begin{array}{l}\text { 1000-Seed } \\
\text { Weight } \\
(\mathrm{g})\end{array}$ & Biological & Grain & Straw & \\
\hline \multicolumn{9}{|l|}{ Tillage systems } \\
\hline $\begin{array}{l}\mathrm{Z}_{1} \text { - Conventional tillage (6 harrowing } \\
+ \text { planking) }\end{array}$ & 395 & 47 & 1.93 & 41.11 & 14.98 & 5.67 & 9.31 & 0.38 \\
\hline $\mathrm{Z}_{2}-$ Zero tillage & 391 & 46 & 1.90 & 41.69 & 13.64 & 5.32 & 8.30 & 0.39 \\
\hline $\mathrm{Z}_{3}$ - Zero tillage + mulch & 411 & 49 & 1.94 & 43.53 & 15.09 & 5.72 & 9.37 & 0.38 \\
\hline S.Em. \pm & 5.79 & 0.62 & 0.06 & 0.59 & 0.27 & 0.04 & 0.17 & 0.001 \\
\hline C.D. $(\mathrm{P}=0.05)$ & 20.02 & 2.14 & NS & 2.05 & 0.94 & 0.15 & 0.59 & 0.003 \\
\hline \multicolumn{9}{|l|}{ Irrigation levels } \\
\hline $\begin{array}{l}\mathrm{I}_{1}=\text { Four irrigations (CRI, late } \\
\text { jointing, flowering, milking) }\end{array}$ & 378 & 46 & 1.91 & 42.11 & 14.95 & 5.60 & 9.35 & 0.37 \\
\hline $\begin{array}{l}\mathrm{I}_{2}=\text { Five irrigations (CRI, late } \\
\text { tillering, late jointing, flowering, } \\
\text { milking) }\end{array}$ & 381 & 47 & 1.98 & 42.4 & 15.36 & 6.01 & 9.35 & 0.39 \\
\hline $\begin{array}{l}\mathrm{I}_{3}=\text { Six irrigations }(\mathrm{CRI} \text {, late tillering, } \\
\text { late jointing, flowering, milking, } \\
\text { dough) }\end{array}$ & 383 & 48 & 2.06 & 42.58 & 15.56 & 6.05 & 9.51 & 0.39 \\
\hline $\begin{array}{l}\mathrm{I}_{4}=\text { Seven irrigations ( } 15 \text { DAS, CRI, } \\
\text { late tillering, late jointing, flowering, } \\
\text { milking, dough) }\end{array}$ & 387 & 49 & 1.99 & 42.12 & 16.14 & 5.84 & 10.3 & 0.36 \\
\hline S.Em. \pm & 5.11 & 0.48 & 0.05 & 0.58 & 0.18 & 0.04 & 0.12 & 0.001 \\
\hline C.D. $(P=0.05)$ & $\mathrm{NS}$ & NS & NS & NS & 0.55 & 0.17 & 0.37 & 0.003 \\
\hline \multicolumn{9}{|l|}{ Nitrogen levels $(\mathrm{kg} \mathrm{N} / \mathrm{ha})$} \\
\hline $\mathrm{N}_{1}-120$ & 369 & 46 & 1.94 & 42.25 & 14.68 & 5.60 & 9.09 & 0.38 \\
\hline $\mathrm{N}_{2}-150$ & 380 & 46 & 1.96 & 42.44 & 15.26 & 5.99 & 9.27 & 0.39 \\
\hline $\mathrm{N}_{3}-180$ & 389 & 47 & 1.93 & 41.97 & 15.27 & 5.83 & 9.74 & 0.36 \\
\hline S.Em. \pm & 4.93 & 0.53 & 0.05 & 0.60 & 0.12 & 0.05 & 0.09 & 0.0009 \\
\hline C.D. $(\mathrm{P}=0.05)$ & NS & NS & NS & NS & 0.35 & 0.15 & 0.26 & 0.0025 \\
\hline
\end{tabular}

*DAS = Days after sowing, NS= Non significant 
Table 4: Effect of Tillage Systems, Irrigation and Nitrogen Levels on Nutrient Uptake and Quality Parameters of Wheat (Mean of Five Years)

\begin{tabular}{|c|c|c|c|c|c|c|c|}
\hline \multirow{2}{*}{ Treatment } & \multicolumn{4}{|c|}{ Total Nutrient Uptake (kg/ha) } & \multirow{2}{*}{\begin{tabular}{|c|}
$\begin{array}{c}\text { Iron } \\
\text { Uptake }\end{array}$ \\
(g/ha) \\
\end{tabular}} & \multirow{2}{*}{$\begin{array}{c}\text { Protein } \\
\text { Content }(\%)\end{array}$} & \multirow{2}{*}{$\begin{array}{c}\text { Starch } \\
\text { Content } \\
(\%) \\
\end{array}$} \\
\hline & Nitrogen & Phosphorus & Potassium & Sulphur & & & \\
\hline \multicolumn{8}{|l|}{ Tillage systems } \\
\hline $\begin{array}{l}\mathrm{Z}_{1} \text { - Conventional tillage ( } 6 \\
\text { harrowing + planking) }\end{array}$ & 157.82 & 26.4 & 132.3 & 13.6 & 980 & 11.81 & 69.3 \\
\hline $\mathrm{Z}_{2}$ - Zero tillage & 146.16 & 25.4 & 132.2 & 12.9 & 910 & 11.75 & 69.1 \\
\hline $\mathrm{Z}_{3}$ - Zero tillage + mulch & 159.10 & 27.4 & 152.8 & 14.7 & 1120 & 11.95 & 70.4 \\
\hline S.Em. \pm & 1.50 & 0.61 & 1.24 & 0.33 & 8.1 & 0.186 & 1.12 \\
\hline C.D. $(\mathrm{P}=0.05)$ & 5.21 & 2.12 & 4.31 & 1.15 & 28.1 & NS & $\mathrm{NS}$ \\
\hline \multicolumn{8}{|l|}{ Irrigation levels } \\
\hline $\begin{array}{l}\mathrm{I}_{1}=\text { Four irrigations }(\mathrm{CRI}, \\
\text { late jointing, flowering, } \\
\text { milking) }\end{array}$ & 156.86 & 24.9 & 135.7 & 13.8 & 910 & 11.75 & 69.1 \\
\hline $\begin{array}{l}\mathrm{I}_{2}=\text { Five irrigations (CRI, } \\
\text { late tillering, late jointing, } \\
\text { flowering, milking) }\end{array}$ & 168.99 & 26.3 & 141.3 & 14.3 & 980 & 11.75 & 69.7 \\
\hline $\begin{array}{l}\mathrm{I}_{3}=\text { Six irrigations (CRI, } \\
\text { late tillering, late jointing, } \\
\text { flowering, milking, dough) }\end{array}$ & 171.1 & 27.3 & 144.6 & 14.9 & 1130 & 11.78 & 69.9 \\
\hline $\begin{array}{l}\mathrm{I}_{4}=\text { Seven irrigations ( } 15 \\
\text { DAS, CRI, late tillering, } \\
\text { late jointing, flowering, } \\
\text { milking, dough) }\end{array}$ & 176.31 & 27.8 & 146.8 & 15.6 & 1280 & 11.67 & 69.3 \\
\hline S.Em. \pm & 1.77 & 0.75 & 1.60 & 0.37 & 7.0 & 0.185 & 1.29 \\
\hline C.D. $(\mathrm{P}=0.05)$ & 5.27 & 2.23 & 4.75 & 1.09 & 20.8 & NS & NS \\
\hline \multicolumn{8}{|l|}{ Nitrogen levels $(\mathrm{kg} \mathrm{N} / \mathrm{ha})$} \\
\hline $\mathrm{N}_{1}-120$ & 148.36 & 25.2 & 139.6 & 14.3 & 1010 & 11.75 & 69.5 \\
\hline $\mathrm{N}_{2}-150$ & 160.62 & 27.4 & 145.3 & 15.6 & 1190 & 12.21 & 69.9 \\
\hline $\mathrm{N}_{3}-180$ & 174.10 & 29.3 & 150.2 & 16.7 & 1290 & 12.33 & 69.2 \\
\hline S.Em. \pm & 1.54 & 0.82 & 1.82 & 0.40 & 3.2 & 0.125 & 0.03 \\
\hline C.D. $(\mathrm{P}=0.05)$ & 4.36 & 2.31 & 5.14 & 1.12 & 12.2 & 0.354 & $\mathrm{NS}$ \\
\hline
\end{tabular}

*DAS = Days after sowing, NS= Non significant

Table 5: Economics of Tillage Systems, Irrigation and Nitrogen Levels (Mean of Five Years) in Wheat

\begin{tabular}{|c|c|c|c|c|c|}
\hline Treatment & $\begin{array}{l}\text { Cost of } \\
\text { cultivation } \\
\text { (₹) }\end{array}$ & $\begin{array}{l}\text { Gross } \\
\text { return } \\
(₹)\end{array}$ & $\begin{array}{l}\text { Net return } \\
(₹)\end{array}$ & $\begin{array}{l}\text { Out: Input } \\
\text { ratio } \\
(\text { ₹:₹) }\end{array}$ & $\begin{array}{l}\text { B:C ratio } \\
(₹: ₹)\end{array}$ \\
\hline \multicolumn{6}{|l|}{ Tillage systems } \\
\hline $\begin{array}{l}\mathrm{Z}_{1} \text { - Conventional tillage (6 harrowing }+ \\
\text { planking) }\end{array}$ & 23850 & 96220 & 72370 & 4.03 & 3.04 \\
\hline $\mathrm{Z}_{2}$ - Zero tillage & 19516 & 89590 & 70074 & 4.59 & 3.59 \\
\hline $\mathrm{Z}_{3}-$ Zero tillage + mulch & 22700 & 97920 & 75220 & 4.31 & 3.31 \\
\hline \multicolumn{6}{|l|}{ Irrigation levels } \\
\hline $\begin{array}{l}\mathrm{I}_{1}=\text { Four irrigations (CRI, late jointing, } \\
\text { flowering, milking) }\end{array}$ & 22400 & 94860 & 72460 & 4.23 & 3.23 \\
\hline $\begin{array}{l}\mathrm{I}_{2}=\text { Five irrigations }(\mathrm{CRI} \text {, late tillering, } \\
\text { late jointing, flowering, milking) }\end{array}$ & 23500 & 102000 & 78500 & 4.34 & 3.34 \\
\hline $\begin{array}{l}\mathrm{I}_{3}=\text { Six irrigations }(\mathrm{CRI}, \text { late tillering, } \\
\text { late jointing, flowering, milking, } \\
\text { dough) }\end{array}$ & 24600 & 103530 & 78930 & 4.21 & 3.21 \\
\hline $\begin{array}{l}\mathrm{I}_{4}=\text { Seven irrigations ( } 15 \text { DAS, CRI, } \\
\text { late tillering, late jointing, flowering, } \\
\text { milking, dough) }\end{array}$ & 25700 & 102950 & 77250 & 4.01 & 3.01 \\
\hline
\end{tabular}


Long Term Impact of Tillage Systems, Irrigation and Nitrogen on Soil Properties, Growth, Yield, Nutrient Uptake and Quality of Wheat (Triticum Aestivum L.)

Table 5: Contd.,

\begin{tabular}{|l|c|c|c|c|c|}
\hline Nitrogen levels $(\boldsymbol{k g}$ N/ha) & & & & & \\
\hline $\mathrm{N}_{1}-120$ & 22825 & 89250 & 66425 & 3.91 & 2.91 \\
\hline $\mathrm{N}_{2}-150$ & 23022 & 98430 & 75408 & 4.28 & 3.28 \\
\hline $\mathrm{N}_{3}-180$ & 23220 & 96540 & 73320 & 4.16 & 3.16 \\
\hline
\end{tabular}


